Research article

\title{
INVESTIGATIONS ON THE RESISTANCE OF PORCINE COMMENSAL E. COLI ISOLATES TO BETA LACTAMS
}

\author{
URUMOVA Valentina* \\ Department of Veterinary Microbiology, Infectious and Parasitic Diseases, Faculty of Veterinary \\ Medicine, Trakia University, Stara Zagora, Student campus, Bulgaria
}

(Received 27 February; Accepted 27 May 2015)

\begin{abstract}
The aim of this study was to describe the prevalence of antibiotic resistance to betalactams and to evaluate two resistance genes bla ${ }_{\mathrm{TEM}}$ and bla ${ }_{\mathrm{OXA}-1}$ in Escherichia coli isolates from faeces on six swine farms in the Republic of Bulgaria. A total of 186 E. coli isolates from 192 faecal swabs were tested by the disk diffusion method to determine resistance patterns to 11 antimicrobial agents. Resistance to beta-lactams was determined by disk diffusion method, E-test, micro-broth dilution method and PCR. About $40.3 \%$ of the E. coli isolates from swine were resistant to ampicillin. The highest resistance was observed in E.coli isolates from weaned pigs to ampicillin $-60.0 \%$ and to cephalotin $45.5 \%$. The E. coli isolates resistant to beta-lactams were examined for the presence of bla $_{\text {TEM }}$ and bla OXA-1 $_{\text {genes. The most common bla gene identified was bla }}$ TEM, which was found in $92.0 \%$ of swine isolates.
\end{abstract}

Key words: commensal Escherichia coli, ESBL, pigs, resistance to beta-lactams

\section{INTRODUCTION}

Enzymes hydrolysing beta-lactam antibiotics determine one of the commonest mechanisms of resistance among clinically relevant Enterobacteriaceae. Due to the fact that penicillins, cephalosporins, and carbapenems are preferred therapeutic options in the treatment of various infectious diseases in humans, the presence and structure of beta-lactamases are essential for the selection of these chemotherapeutics. Extended spectrum beta-lactamases (ESBL) are hydrolases acting on penicillins, broad-spectrum cephalosporins and monobactams, originating from TEM and SHV-enzymes. The antibacterial therapy in cases where ESBL-producing strains are involved is often impeded further by the presence of co-transfer with participation of plasmids, genes of resistance mediating resistance to aminoglycosides and fluoroquinolones. A horizontal gene transfer of resistance from commensal E. coli organisms, possessing ESBL genes to microbial pathogens such as Klebsiella spp. is possible [1]. Unfortunately, the efficacy carbapenems which are drugs of choice for treatment of infections caused by ESBL

*Corresponding author: e-mail: valentina_62@abv.bg 
producing strains, is also partially compromised due to the spread of resistance in some bacterial species, Stenotrophomonas spp. and Pseudomonas spp. TEM-1 that determines the resistance to ampicillin, penicillin and first-generation cephalosporins is involved in $90 \%$ of cases of ampicillin-resistant E. coli infections [2]. During the last 15 years, the prevalence of ESBL as CTX-M-1, CTX-M-2, CTX-M-14 in Europe, mainly among domestic poultry, was reported by several researchers [3-6]. From the point of view of the risk associated to the selective pressure from use of chemotherapeutics in difference groups of livestock species, it could be pointed out that aminopenicillins are frequently used in different domestic animals and poultry farming in particular. Data of EMEA (1999) demonstrate a relatively high rate of utilisation of penicillins in veterinary medicine in European Union (EC) countries, coming third (9\%) after tetracyclines and macrolides. Third- and fourth generation cephalosporins are the second group of choice for treatment of cattle, applied in the therapy of infections as metritis, hoof diseases, mastitis, respiratory infections in ruminants, swine and horses, and skin infections, acute peritonitis, osteomyelitis, and respiratory infections in dogs and cats [7].

In Bulgaria during the latest ten years monitoring of antimicrobial resistance in isolates from farm animals concerns only zoonotic bacterial species like Salmonella spp. according the recommendation of European Committee.

\section{MATERIAL AND METHODS}

Farms and antibiotic use policy:

\section{Farm - I}

Total number of sows -1100

Antibiotic use policy: Wide use of colistin sulfate for metaphylaxis of post weaning enteritis, etiologically associated with EHEC and ETEC in growing pigs. Wide use of amoxicillin and ceftiofur in various clinical forms of $S$. suis infection in suckling and growing pigs. The farm was free of dysentery and colonic spirochaetosis, thus did not require the application of tiamulins and tetracyclines.

\section{Farm - II}

Total number of sows - 1180

Antibiotic use policy: Wide use of colistin sulfate for metaphylaxis of post weaning enteritis, etiologically associated with EHEC and ETEC in growing pigs. Due to the stationary nature of swine dysentery and proliferative enteropathy, a continuous use of tiamulin preparations and tetracyclines as well as tylosin is noted. Lincomycin and lincospectin are also commonly used.

\section{Farm - III}

Total number of sows -4000 
Antibiotic use policy: Wide use of ceftiofur for metaphylaxis of streptococcal infections in suckling and growing pigs, as well as administration of tetracyclines, lincomycin and amoxicillin.

\section{Farm - IV}

Total number of sows -1500

Antibiotic use policy: Wide use of ceftiofur for metaphylaxis of streptococcal infections in suckling and growing pigs. Due to the stationary nature of swine dysentery and colonic spirochaetosis, lincospectin, tiamulins often combined with oxy- or chlortetracycline are used.

Farm - V

Total number of sows -410

Antibiotic use policy: Wide use of ceftiofur for metaphylaxis of streptococcal infections in suckling and growing pigs. Wide use of amoxicillin for therapy of erysipelas.

\section{Farm - VI}

Total number of sows -650

Antibiotic use policy: Limited use of antibiotics and a quality biosecurity program. Permanent use of colistin for metaphylaxis of EHEC and ETEC in weaned and growing pigs and also use of gentamicin and enrofloxacin for therapy of enteritis.

With regard to the antibiotic policy related to the use of beta-lactam chemotherapeutics on the six farms, it should be noted that only in three of them, due to frequent outbreaks of erysipelas and problems with Streptococcus suis infections in suckling and weaned pigs, beta-lactams, amoxicillin and ceftiofur are more commonly employed.

\section{Sample collection}

Between January and May 2014, 192 faecal swab samples were collected from different age groups of pigs (suckling, weaned, finisher) from 6 farrow-to-finish farms. Faecal swabs were transported in Stuart Transport Medium (BD, USA) at low temperature within 18-24 hours.

\section{Culturing and identification of $E$. coli isolates}

Swabs were cultured on McConkey agar (Emapol, Poland) at $37{ }^{\circ} \mathrm{C}$ for 24 hours. Lactose-positive colonies were subcultured onto TSI agar (BD, USA) and submitted to preliminary biochemical typing via citrate utilisation, methyl red, Vogues Proskauer and indole production tests. The identification of strains was performed with kits for non-fermenting and enteric bacteria (BD, USA) on the semi-automated identification Crystal BBL system.

\section{Determination of the sensitivity of $E$. coli isolates to antibiotics}

The sensitivity of E. coli isolates to 11 chemotherapeutics was evaluated by the disk diffusion method as per CLSI, using Muller-Hinton agar (Emapol, Poland) and 
antibiotic disks (Emapol, Poland), loaded as followed: ampicillin (10 $\mu \mathrm{g})$, amoxicillin/ clavulanic acid $(20 / 10 \mu \mathrm{g})$, cephalotin $(30 \mu \mathrm{g})$, ceftazidime $(10 \mu \mathrm{g})$, cefotaxime $(30 \mu \mathrm{g})$, gentamicin $(10 \mu \mathrm{g})$, streptomycin $(10 \mu \mathrm{g})$, spectinomycin $(25 \mu \mathrm{g})$, tetracycline $(30 \mu \mathrm{g})$, ciprofloxacin $(5 \mu \mathrm{g})$, sulfamethoxazole $(25 \mu \mathrm{g})$. To determine the sensitivity of isolates to beta lactams, ampicillin, cephalotin, cefotaxime and ceftazidime, the synergic amoxicillin/clavulanic acid $(20 / 10 \mu \mathrm{g})$ test was used. Antibiograms were controlled with a reference strain Escherichia coli ATTC 25922.

The cephalotin MIC were determined with micro-broth dilution test and cationadjusted Muller-Hinton broth (Emapol, Poland), by preparation of doubling dilutions of cephalotin (Sigma-Aldrich) within $0.01-128 \mu \mathrm{g} / \mathrm{mL}$. MIC for ampicillin and amoxicillin/clavulanic acid were defined by Etest strips (AB Biodisk, Solna Sweden). MICs were interpreted according to epidemiological criteria (EUCAST, www.eucast. org).

\section{Determination of resistance genes to beta-lactams in commensal E. coli}

DNA extraction. For DNA extraction, 24-hour cultures incubated at $37^{\circ} \mathrm{C}$, respectively 3-4 colonies on McConkey agar were suspended in $100 \mu \mathrm{l}$ sterile distilled water free of inhibitors for molecular diagnostics (Qiagen). The DNA extraction kit DNeasy Blood Tissue Kit (Qiagen) was used.

Detection of resistancegenes. The presence of resistancegenestobeta-lactamantibiotics, $b_{\text {TEM }}$ and $b l a_{\text {OXA- } 1}$ was detected by PCR. The primers sequences for bla ${ }_{\text {TEM }}$ gene were F- 5

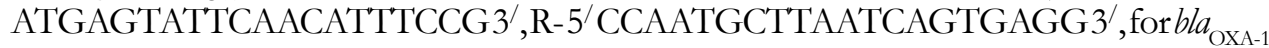
F-5/ACACAATACATATCAACTTCGC-3', R-5/AGTGTGTTTAGAATGGTGATC-3/ [9,10]. PCR assays in $25 \mu \mathrm{l}$ final volume, contained $12.5 \mu \mathrm{l}$ Taq PCR Master mix (Qiagen) and $3 \mu \mathrm{lDNA}$ template. The PCR reaction for bla ${ }_{\mathrm{TEM}}$ consisted of an initial activation step at $94^{\circ} \mathrm{C}$ for $5 \mathrm{~min}$, followed by 30 cycles of DNA denaturation at $94^{\circ}$ $\mathrm{C}$ for $1 \mathrm{~min}$, primer annealing at $55^{\circ} \mathrm{C}$ for $1 \mathrm{~min}$, and primer extension at $72^{\circ} \mathrm{C}$ for $1 \mathrm{~min}$, and final extension for $10 \mathrm{~min}$ at $72^{\circ} \mathrm{C}$. The PCR reaction for bla oxA $-1_{\text {included }}$ a 5 -min denaturation at $96^{\circ} \mathrm{C}$, followed by 35 cycles of denaturation $96^{\circ} \mathrm{C}$ for $1 \mathrm{~min}$, annealing at $61^{\circ} \mathrm{C}$ for $1 \mathrm{~min}$ and extension at $72^{\circ} \mathrm{C}$ for $2 \mathrm{~min}$ and final extension of $72^{\circ} \mathrm{C}$ for $10 \mathrm{~min}$. All reactions were carried out in Eppendorf gradient thermal cycler. Ten $\mu \mathrm{L}$ aliquots of PCR products were analyzed by gel electrophoresis with $1.5 \%$ agarose (Peqlab, Germany). Gels were stained with ethidium bromide at $10 \mu \mathrm{g} / \mathrm{mL}$ and visualized by UV transillumination. A 100- bp DNA ladder plus (Qiagen) was used as the marker. Positive control strain E. coli ATCC 35218 was used. Negative controls were PCR mixtures with the addition of water in place of template DNA.

\section{RESULTS}

Number of isolates: The total number of E. coli isolates from examined faecal swabs obtained from different age categories at studied farms was 186. 


\section{Resistance patterns}

Table 1. Prevalence of antibiotic resistance in E. coli strains from pigs from 6 farrow-to finish farms

\begin{tabular}{lccccc}
\hline \multirow{2}{*}{ Antibiotic } & \multicolumn{5}{c}{ Resistant isolates (\%) } \\
\cline { 2 - 6 } & $\begin{array}{c}\text { Suckling pigs } \\
\mathbf{n = ~ 4 2}\end{array}$ & $\begin{array}{c}\text { Weaned pigs } \\
\mathbf{n = 9 0}\end{array}$ & $\begin{array}{c}\text { Finishers } \\
\mathbf{n = 5 4}\end{array}$ & $\begin{array}{c}\text { Total } \\
\mathbf{n = 1 8 6}\end{array}$ & $\mathbf{9 5 \% \mathbf { C . L } .}$ \\
\hline Ampicillin & $9(21.4)$ & $54(60.0)$ & $12(22.2)$ & $75(40.3)$ & $33.4 \div 47.4$ \\
\hline Amoxicillin/clavulanic acid & $1(2.3)$ & $3(3.3)$ & 0 & $4(2.1)$ & $0.5 \div 4.5$ \\
Cephalotin & $3(7.1)$ & $41(45.5)$ & $4(7.4)$ & $48(25.8)$ & $19.8 \div 32.3$ \\
\hline Ceftazidime & 0 & 0 & 0 & 0 & \\
Cefotaxime & 0 & 0 & 0 & 0 & \\
Gentamicin & $3(7.1)$ & $23(25.5)$ & $4(7.4)$ & $30(16.1)$ & $11.2 \div 21.7$ \\
\hline Streptomycin & $29(69)$ & $75(83.3)$ & $40(74.0)$ & $144(77.4)$ & $71.0 \div 83.1$ \\
\hline Spectinomycin & $19(45.2)$ & $66(73.3)$ & $35(64.8)$ & $120(64.5)$ & $57.5 \div 71.2$ \\
Tetracycline & $28(66.6)$ & $79(87.7)$ & $32(59.2)$ & $139(74.7)$ & $68.1 \div 80.7$ \\
\hline Ciprofloxacin & $2(4.7)$ & $7(7.7)$ & 0 & $9(4.8)$ & $2.2 \div 8.3$ \\
Sulfamethoxazole & $17(40.5)$ & $55(61.1)$ & $25(46.3)$ & $97(52.1)$ & $44.9 \div 59.2$ \\
\hline
\end{tabular}

Table 1 presents the results on the spread of resistance patterns among commensal E. coli strains isolated from the three age categories of pigs to 11 chemotherapeutics, obtained by the disk diffusion test. The highest percentage of resistance was exhibited to ampicillin $-60.0 \%$ of isolates from weaned pigs, $22.2 \%$ in finishers and $21.4 \%$ from neonatal pigs. With respect to cephalotin, the highest resistance $(45.5 \%)$ was also determined in weaned pigs, whereas suckling pigs and finisher pigs showed significantly lower incidence: $7.1 \%$ and $7.4 \%$, respectively. Resistance to the combination amoxicillin/clavulanic acid was found out in 4 strains (2.1\%), originating from one of the 6 farms. In the disk diffusion test, the behaviour of 2 isolates from two different farms to third-generation cephalosporins was characterised with inhibition zones of $20 \mathrm{~mm}$ to ceftazidime and $22 \mathrm{~mm}$ to cefotaxime. The results from the synergic test with amoxicillin/clavulanic acid however were negative.

Polyresistance patterns in the studied E. coli strains showed that the resistance to ampicillin and cephalotin was most frequently seen together with resistance to tetracycline, streptomycin/spectinomycin and sulfonamides (37.6\%).

Table 2. Distribution of MICs among commensal E. coli $(\mathrm{n}=186)$ isolated from pigs

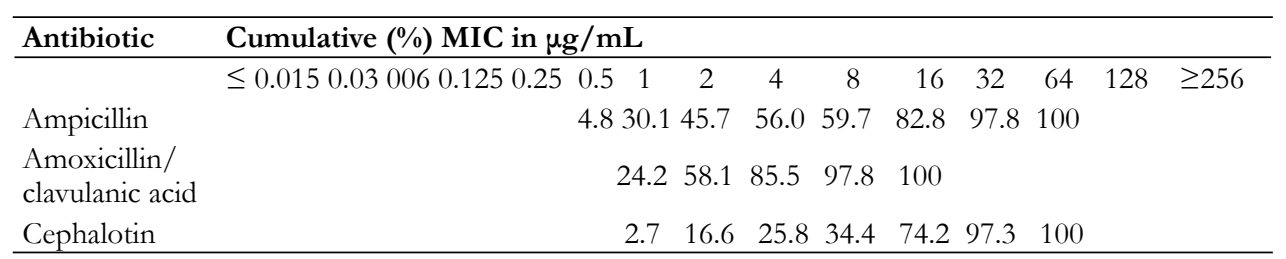


Table 2 presents the cumulative percentages of MICs determining the resistance among commensal E. coli isolates to beta-lactams. In the studied strains, $\mathrm{MIC}_{90}$ was $16 \mu \mathrm{g} / \mathrm{mL}$ against ampicillin and cephalotin, and $4 \mu \mathrm{g} / \mathrm{mL}$ to amoxicillin/clavulanic acid.

\section{Occurrence of resistance determinants}

Table 3 presents data about the prevalence of resistance genes in E. coli and corresponding resistance phenotypes to beta-lactam antimicrobial agents. Among resistant isolates recovered from the different age categories, bla ${ }_{\text {TEM }}$ was established in those possessing a phenotype of resistance only to ampicillin (73), to ampicillin and cephalotin (44), ampicillin and amoxicillin/clavulanic acid (4). None of strains resistant to beta-lactams have shown bla OxA-1 $^{\text {. }}$

Table 3. Occurrence of resistance genes determined among commensal E. coli $(\mathrm{n}=186)$ from pigs

\begin{tabular}{|c|c|c|c|c|}
\hline \multirow[t]{2}{*}{ Group of animals } & \multirow{2}{*}{\multicolumn{2}{|c|}{$\begin{array}{c}\text { Phenotype of resistance } \\
\text { to beta-lactams }\end{array}$}} & \multicolumn{2}{|c|}{$\begin{array}{c}\text { Genotype of resistance } \\
\text { to beta-lactams }\end{array}$} \\
\hline & & & bla $_{\text {TEM }}$ & bla $_{\text {oxA-1group }}$ \\
\hline \multirow{3}{*}{$\begin{array}{l}\text { Suckling pigs } \\
\mathrm{n}=42\end{array}$} & A & 9 & $b l a_{\mathrm{TEM}}$ & - \\
\hline & A Cf & 3 & $b l a a_{\mathrm{TEM}}$ & - \\
\hline & A AMC & 1 & $b l a_{\text {TEM }}$ & - \\
\hline \multirow{3}{*}{$\begin{array}{l}\text { Weaned pigs } \\
\mathrm{n}=90\end{array}$} & A & 54 & $b l a_{\text {TEM }}$ & - \\
\hline & A Cf & 41 & $b l a_{\mathrm{TEM}}$ & - \\
\hline & A AMC & 3 & $b l a_{\mathrm{TEM}}$ & - \\
\hline \multirow{2}{*}{$\begin{array}{l}\text { Finisher pigs } \\
\mathrm{n}=54\end{array}$} & A & 12 & $b l a_{\mathrm{TEM}}$ & - \\
\hline & A Cf & 4 & $b l a_{\mathrm{TEM}}$ & - \\
\hline
\end{tabular}

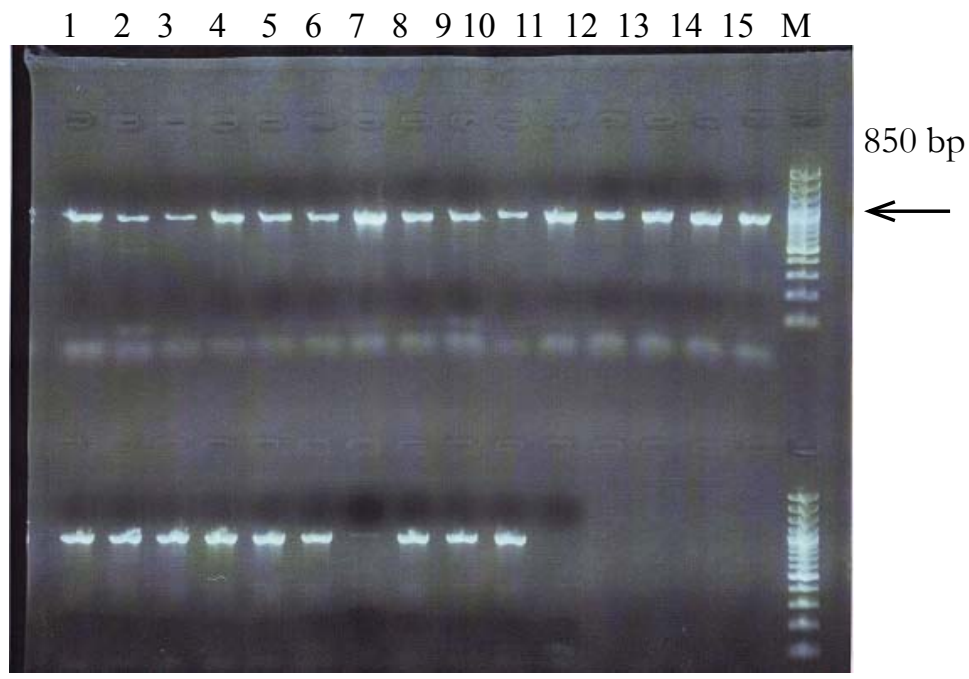

Figure1. Electrophoretic separation of products of amplification of a $850 \mathrm{bp}$ fragment of bla ${ }_{\text {TEM }}$ gene: Lanes 1 to 24, lane 25-Positive control, lane 26- Negative control, M-100bpDNA ladder. 
Fig. 1 depicts electrophoretic patterns of amplification products after amplification of a 850 bp fragment from bla TEM.

\section{DISCUSSION}

In the present study, no E. coli isolates ESBL producers resistant to cefotaxime and ceftazidime were found, the level of resistance to aminopenicillins (40.3\%) and firstgeneration cephalosporins $(25.8 \%)$ were high, as well as polyresistant strains $(37.6 \%)$.

The EFSA report (2011) outlines the particular significance of resistance in indicator E. coli from domestic animals to third- and fourth generation cephalosporins and to fluoroquinolones used in medical practice. EFSA stated that reports about the spread of ESBL producing (TEM, SHV, CTX-M) Enterobacteriaceae isolated from livestock and foodstuffs have significantly increased during the last decade. Using data from DANMAP (2009), the report noted a low prevalence $(0.7 \%-3.3 \%)$ of cefotaximeresistant E. coli isolates from poultry, pork and beef meats and a higher occurrence of resistant E. coli $(36 \%)$ isolated from imported poultry meat. Also, data about the prevalence of ESBL producers among swine (11\%) and the presence of the commonest subtype of CTX-M beta-lactamases - CTX-M-1 (66\%) is pointed out. During the last years, a number of authors from several European countries reported data about the incidence of ESBL-producing porcine commensal E. coli [13, 14, 15, $16,17,18,19]$. In some European countries, a high percentage $(52 \%)$ of resistance to ampicillin in E. coli commensals isolated from cattle, poultry and pigs was outlined [20]. In the Netherlands and Sweden, Van Den Bogaard et al. [21] established a high percentage of commensal E. coli isolates from swine, resistant to amoxicillin (51\%). Brinas et al. [3] also reported high MIC $\geq 256 \mu \mathrm{g} / \mathrm{mL}$ in 62 coli strains isolated from domestic animals and foods. The authors supported the resistance to aminopenicillins with detection of the presence of bla ${ }_{\text {TEM }}$ in $83 \%$ of resistant colibacteria isolates. In France, data from 2003-2004 published by AFSA [22] provide information about low sensitivity to amoxicillin (39.7\%.) in porcine E. coli commensals. In Denmark the resistance to ampicillin has increased from 11\% in 2002 to $32 \%$ in 2004 in E. coli strains from pigs [23]. Kozak et al. [24] also determined comparable level of resistance to ampicillin (22\%) and $4 \%$ to amoxicillin/clavulanic acid in commensal colibacteria from swine. Unlike others, Stannarius [25] described a low resistance to ampicillin $(8.6 \%)$ in weaned pigs and only $5.8 \%$ in finisher pigs.

In the context of reviewed information, it should be noted that during the last decade, antibiotic resistance among indicator bacteria from domestic animals has not been monitored in the Republic of Bulgaria. Such data would permit to perform an analysis and evaluation of risk for spread of resistance in pig farms.

Our data on the resistance to ampicillin are similar to that reported by Wasyl [26] $42.3 \%$ resistance to ampicillin in domestic animal E. coli strains on the basis of high MICs $-64 \mu \mathrm{g} / \mathrm{mL}$, detected in most isolates. Also, the data of Mazurek [27] about 
a slightly higher resistance to ampicillin in porcine E. coli commensals (49.3\%) were attributed to the high prevalence only of bla TEM. The authors demonstrated a high resistance to cephalotin - 44.2\% compared to our results. The high resistance to ampicillin (95.5\%) was also determined in S. Infantis isolated from poultry carcasses in Serbia by Raš̉eta et al. [28]. The data reported by Guerra et al. [29] are identical to ours as the prevalence of bla ${ }_{\text {TEM }}$ in $92 \%$ of resistant E. coli commensals in domestic animals was concerned.

Conclusion: A decade ago, monitoring of the spread of resistance to chemotherapeutics among various pathovarieties of E. coli from swine (ETEC, EHEC) in the Republic of Bulgaria established that the prevalence of resistance to amoxicillin and ampicillin was $19.1 \%$. Since then, the criteria for evaluation of resistance to aminopenicillins have changed, which also had some effect on the present results. Taking into consideration that fact that in general, the resistance to chemotherapeutics in pathogenic Enterobacteriaceae strains is higher than that observed in commensal E. coli, the present study provided evidence about an alarming twice as high resistance to aminopenicillins.

\section{REFERENCES}

1. Levy SB, Marshall B: Antibacterial resistance worldwide: causes, challenges and responses. Nature Medicine Suppl 2004, 10: 122-129.

2. Livermore DM: $\beta$-lactamases in laboratory and clinical resistance. Clin Microbiol Rev 1995, 8: 557-584.

3. Brinas L, Zarazaga M, Sȧenz Y, Ruiz-Larrea F, Torres C: $\beta$-lactamases in ampicillin-resistant Escherichia coli isolates from foods, humans and healthy animals. Antimicrob. Agents Chemother 2002, 46: 3156-3163.

4. Costa D, Vinue L, Poeta P, Coelho A, Matos M, Sảenz Y, Somalo S, Zarazaga M, Rodrigues J, Torres C: Prevalence of extended-spectrum beta-lactamase-producing isolates in faecal samples in broilers. Vet Microbiol 2009, 138: 339-363.

5. Girlich D, Poirel L, Carattoli A, Kemf I, Lartigue M, Bertini A, Nordmann P.. Extendedspectrum $\beta$-lactamase CTX-M-1 in Escherichia coli isolates from healthy poultry in France. Appl Environ Microbiol 2007, 73: 4681-4685.

6. EMEA: Antibiotic resistance in the European Union associated with therapeutic use of veterinary medicines. 1999.

7. Batchelor M Threlfall EJ, Liebana E: Cephalosporin resistance among animal-associated Enterobacteria: a current perspective. Expert Review of Anti-infective Therapy 2005, 3: 403 417.

8. CLSI, Clinical and Laboratory Standards Institute. 2008. Performance Standards for antimicrobial disk and dilution susceptibility tests for bacterial isolates from animals, CLSI/ M31-A3.

9. Arlet G, Brami G, Decre D, Flippo A, Gaillot O, Lagrange PH, Philippon AM: Molecular characterization by PCR - restriction fragment length polymorphism of TEM betalactamases. FEMS Microbiology Letters 1995, 134: 203-208.

10. Steward CD, Rasheed J, Hubert SK, Biddle JW, Raney PM, Anderson GJ, Williams PP, Brittain KL, Oliver A, McGowan JE, Tenover FC: Characterization of clinical isolates 
of Klebsiella pneumoniae from 19 laboratories using National Committee for Clinical Laboratory Standards extended-spectrum $\beta$-lactamase detection method. J Clin Microbiol 2001, 39: 2864-2872.

11. EFSA: Scientific Opinion on the public health risks of bacterial strains producing extendedspectrum $\beta$-lactamases and/or AmpC $\beta$-lactamases in food and food-producing animals. EFSA Panel on Biological Hazards (BIOHAZ). European Food Safety Authority (EFSA), Parma, Italy. EFSA Journal 2011, 9(8):2322.

12. DANMAP: Use of antimicrobial agents and occurrence of antimicrobial resistance in bacteria from food animals, foods and human in Denmark. Copenhagen, Denmark 2009.

13. Blanc V, Mesa R, Montserrat S, Lavilla S, Prats G, Miro E, Navarro F, Cortès P, Llagostera M: ESBL- and plasmidic class $C \beta$-lactamase- producing E. coli strains isolated from poultry, pig and rabbit farms. Vet Microbiol 2006, 118: 299-304.

14. Wu Sh, Chouliara E, Hasman H, Daldgaard A, Vieira A, Jensen LB.. Detection of single isolate of CTX-M-1 producing Escherichia coli from healthy pigs in Denmark. J Antimicrob Chemother 2008, 61:747-749.

15. Escudero E, Vinue L, Teshager T, Torres C, Moreno MA:. Resistance mechanisms and farm-level distribution of fecal Escherichia coli isolates resistant to extended-spectrum caphalosporins in pigs in Spain. Research in Veterinary Science 2010, 88: 83-87.

16. Gonçalves A, Torres C, Silva N, Carneiro C, Hajer R, Coelho C, Araứjo C, Rodrigues J, Vinue L, Somalo S, Poeta P, Igrejas G: Genetic characterization of extended-spectrum beta-lactamases in Escherichia coli isolates of pigs from a Portuguese intensive swine farm. Foodborne Path Dis 2010, 7: 1569-1573.

17. Horton RA, Randall LP, Snary EL, Cockrem H, Lotz S, Wearing H, Duncan D, Rabie A, McLaren I, Watson E, La Ragione RM, Coldham NG: Fecal carriage and shedding density of CTX-M extended-spectrum $\beta$-lactamase - producing Escherichia coli in cattle, chickens, and pigs: implications for environmental contamination and food production. Appl Environ Microbiol 2011, 77: 3715-3719.

18. Wasyl D, Hasman H, Cavaco LM, Aarestrup FM: Prevalence and characterization of cephalosporin resistance in nonpathogenic Escherichia coli from food-producing animals slaughtered in Poland. Microb Drug Resistance 2012,18: 79-82.

19. Rodrigues C, Machado E, Peixe L, Novais A: IncI1ST3 and IncN/ST1 plasmids drive the spread of bla TEM-52 and bla CTX-M-1/-32 in diverse Escherichia coli clones from different piggeries. J Antimicrob Chemother 2013, 68: 12245-2248.

20. Bywater R, Deluyker H, Deroover E, de Jong A, Marion H, McConville M, Rowan T, Shryock T, Shuster D, Thomas V, Valle M, Walters J: A European survey of antimicrobial susceptibility among zoonotic and commensal bacteria isolated from food-producing animals. J Antimicrob Chemother 2004, 54: 744-754.

21. Van den Bogaard AE, London N, Stobberingh EE: Antimicrobial resistance in pig faecal samples from Netherlands (five abattoirs) and Sweden. J Antimicrob Chemother 2000, 45: 663-671.

22. AFSA: French antimicrobial resistance monitoring in bacteria from animal origin (FARM 2003-2004). Agence Fransaise de Secirite Sanitaire des Aliments 2006, 61pp. http://www. afssa.fr/Documents/SANT-Ra-FARM.

23. DANMAP: Use of antimicrobial agents and occurrence of antimicrobial resistance in bacteria from food animals, foods and human in Denmark. Copenhagen, Denmark 2005.

24. Kozak G., Boerlin P., Janecko N., Ried-Smith R. J., Jardine C. 2009. Antimicrobial resistance in Escherichia coli isolates from swine and wild small mammals in the proximity of swine 
farms and in the natural environments in Ontario, Canada. Appl. Envornm. Microbiol., 75, 3, 559-566.

25. Stannarius C, Bürgi E, Regula G, Zychowska MA, Zwifel C, Stephan R: Antimicrobial resistance in Escherichia coli strains isolated from Swiss weaned pigs and sows.Scheiz Arch Tierhelic 2009, 151: 119-125.

26. Wasyl D, Hoszowski A, Zajac M, Szulowski K: Antimicrobial resistance in commensal Escherichia coli isolated from animals at slaughter. Front Microbiol /doi:10.3389/ fmicb.2013.0021.

27. Mazurek J, Pusz P, Bok E, Stosik M, Baldy-Chudzik K: The phenotypic and genotypic characteristics of antibiotic resistance in Escherichia coli isolated from farm animals with different exposure to antimicrobial agents. Polish J Microbiol 2013, 62: 173-179.

28. Raš̉eta M, Teodorovic V, Buncic O, Katic V, Brankovic Lazic I, Polacek V, Vidanovic D: Antibiotic resistance and molecular studies of Salmonella enterica subsp. enterica serovar infantis isolated in human cases and broiler carcasses. Acta Veterinaria- Beograd 2014, 64 92), 257-268.

29. Guerra B, Junker E, Schroeter A, Malorny B, Lehmann S, Helmuth R: Phenotypic and genotypic characterization of antimicrobial resistance in German Escherichia coli isolates from cattle, swine and poultry. J Antimicrob Chemother 2003, 52: 489-492.

\section{ISPITIVANJE REZISTENCIJE KOMENSALNIH E. COLI IZOLATA OD SVINJA NA BETA LAKTAMSKE ANTIBIOTIKE}

\section{URUMOVA Valentina}

Cilj ispitivanja je bio da se utvrdi prevalencija rezistencije na beta-laktamske antibiotike i da se ustanovi prisustvo dva gena rezistencije bla TEM $^{\text {i bla }}$ oxA-1 kod E. coli izolovane iz fecesa na šest farmi svinja u Republici Bugarskoj. Kod ukupno 185 E. coli izolata iz 192 brisa fecesa ispitana je rezistenciji prema 11 antimikrobnih agenasa primenom disk-difuzije metode. Rezistencija na beta-laktamske antibiotike utvrđivana je primenom disk-difuzione metode, E-testa, mikrodilucione metode i pomoću PCR-a. Oko 40,3\% E. coli izolata iz svinja bila su rezistentna na ampicilin. Najveća rezistencija kod E.coli izolata iz odlučene prasadi je uočena na ampicilin - $60.0 \%$ i cefalotin - 45,5\%. Izolati E. coli rezistentni na na beta-laktamske antibiotike ispitani su na prisustvo bla ${ }_{\text {TEM }} \mathrm{i}$ bla oxA-1 gena. Najčešći bla gen koji je otkriven bio je bla ${ }_{\text {TEM }}$, koji je pronađen u $92,0 \%$ izolata od svinja. 